\title{
Ulkan Paleorift Structure in the South-Eastern Environs of the Siberian Platform: Age, Conditions, Sources, and Geodynamic Setting
}

\author{
V.A. Guryanov, A. Yu. Peskov \\ Kosygin Institute of Tectonics and Geophysics, Far East Branch, Russian Academy of Sciences, ul. Kim Yu \\ Chena, 65, Khabarovsk, 680000 Russia \\ Email: guryanov_v@mail.ru
}

\begin{abstract}
This paper attempts to summarize and systematize findings of geological, geophysical, geochronological and geochemical studies over the past three decades on Late Paleoproterozoic granitoids, basites and sedimentary-volcanic rocks of the Ulkan trough in the southeastern flanking of the Siberian Platform, which make it possible to identify their sources and to reconstruct conditions and geodynamic settings of their formation. Rocks of the Ulkan volcano-plutonic complex are found to form in an anorogenic environment under intra-continental extension in relation to the mantle plume activity at $1.77-1.70 \mathrm{Ga}$. Based on geodynamic criteria, five stages recognised in the evolution of the Ulkan paleorift system can be grouped into three major stages of the Late Paleoproterozoic intra-plate magmatism. The study of data made it apparent that the Ulkan paleorift system has characteristics of a three-armed structure indicative of the intense rifting in response to the hot spot activity; the Ulkan alkaline-granitic batholith with its distinct metallogenic specialization for rare-earth elements (REE) and rare earth metals (REM) could be such a hotspottype diapir. Tectonically, the triple junction appears as a zone that underwent intense intra-plate alkaline-granitic magmatism in the Late Paleoproterozoic and hosts ore targets unique in scale and diversity (Be, Ta, Nb, TR, Zr, U, Au, Li, Sn, Mo, P, and Ti) with ages in the $1.72-1.67$ Ga range. Rare-metal and REE deposits are essentially the product of rare-metal alkaline granitic magmatism and most likely related to the evolution of the mantle source in the course of plume activity. The presence of both subalkaline granitoids and volcanic rocks (K-series) and alkaline granites, comendites and pantellerites (Na-series) intensely fractionated and enriched to a maximum degree in most noncoherent elements, as well as $\mathrm{Zr}, \mathrm{Mn}, \mathrm{F}, \mathrm{Fe}$, Ti, is characteristic of the Ulkan anorogenic magmatism. Granitoids of the Ulkan paleorift structure and its southern flanking foldbelts have mixed mantle-crustal sources. Subalkaline granites are derived from a source containing material from lower continental crust and alkaline granites from a mantle source containing the OIB-type component. The origin of the Ulkan-Bilyakchan volcano-plutonic belt initiated as an intracontinental system along the southeastern edge of the Siberian Platform is considered to be related to hot spots of this type.
\end{abstract}

Keywords: Siberian Platform, Ulkan paleorift, Late Paleoproterozoic, Ulkan volcano-plutonic complex, mantle diapir, Ulkachan Formation, Elgete Formation, Maimakan Complex

\section{Introduction}

Early Precambrian rocks come into greater focus of researchers as they shed light on the early stages of crustal growth. The Ulkan sedimentary-volcanogenic trough sited on the south-eastern edge of the Siberian Platform ranks, as we have got to know recently, among those domains in Eurasia where various non-metamorphic Upper Paleoproterozoic rock formations are well exposed on the surface (Ulkanian). In present-day stratigraphic and magmatic maps for Siberia and the Far East of Russia, the Ulkanian is recognised as a regional geochronological subdivision $[12,13]$. The Ulkanian has a unique combination of properties: completeness of the section, clear stratigraphic relationships with the oldest Lower Mesoproterozoic sequences of the Siberian Platform cover and Lower Paleoproterozoic severely 
folded complexes of the Aldan-Stanovoy shield crystalline basement [19]. The Ulkan trough is located on the south-western flank of one of the largest orogenic structures, i.e. Ulkan-Bilyakchan volcano-plutonic belt $[9,20]$, suggesting its crucial importance when interpreting the evolution of the south-eastern flanking of the Siberian Platform in the Paleoproterozoic. Intraplate alkaline-granite magmatism in the Ulkan basin and at its peripheries was most vividly expressed exhibiting pronounced REE-REM metallogenic specialization. Different isotopic methods were employed to place constraints on the mineralisation age [14, 23]. In fact, the Ulkan magmatism is an example of A-type granitic magmatism [24]. Composionally variable granitoids and associated with them comagmatic volcanic rocks that crystallized from dry and high-temperature magmas enriched in alkalis, rare earths, highly charged cations and halogens constitute A-type granites [25]. A specific feature of these granites is that they contain iron-enriched ferro-magnesian silicates, and alkaline granites contain alkali amphibole and pyroxene and astrophyllite. They are post-tectonic in character and are commonly formed deep in the earth under lithospheric extension, that is, they are either postorogenic or anorogenic. It is generally agreed to associate their formation with continental rift, "hot spot" and large igneous province settings $[2,7,8]$. Granitoids similar in geological position, composition and, probably, mechanism of origin are reported to occur in collision orogens of the southern part of the Siberian platform, where they relate to the final stage of collision processes [6]. The function of A-type granitoids as an indicator in collision structures is to mark the final stages in collision processed corresponding to the change in tectonic settings from compression to extension. Note that A-type granites are often associated with deposits of $\mathrm{Sn}, \mathrm{W}, \mathrm{Be}, \mathrm{Nb}, \mathrm{Ta}, \mathrm{TR}, \mathrm{Au}, \mathrm{U}$ and Fe, such as Piting in Brazil, Thor Lake and Strange Lake in Canada, Zaiplats in South Africa, Katuginskoe of the Aldan-Stanovoi shield, and others.

The Ulkan volcano-plutonic association $(1.77$ - $1.70 \mathrm{Ga}$ ago $)$ is a classic example of intraplate magmatism at its height in the Siberian craton $[12,16]$. Igneous complexes of this association are related to a wide range of deposits containing minerals varying from REM and REE to uranium and gold, a number of them defined as large-, medium- and small-sized by their inferred resources [12, 14, 15]. Volcanogenic-sedimentary and intrusive rocks of the association, as well as associated with them various mineral deposits have been studied in depth over the last 30 years $[9,11,12,14,15,16,17,18,19,22$, 23, 28, 29 and others]. All this allows us to consider the Ulkan sedimentary-volcanogenic trough and the plutonic area of the same name as most interesting and favourable not only for interpretation of rifting processes, but also identification of their conditions, sources as well as reconstruction of geodynamic settings of their formation under conditions of mature continental crust of the south-eastern environs of the Siberian Platform at the turn from the early to late Precambrian. Clearly, addressing these issues requires scientific validation of a new concept, that is, a geodynamic model for the formation of the Ulkan paleorift structure. These are precisely the considerations that define the structure of the paper. This is all the more important given that no major synthesis of advances in reconstructing settings for the formation of the structure (geodynamic model) has been published yet. In this paper, consolidation and interpretation of our own data (published and archived data, geological and tectonic maps, diagrams, stratigraphic columns and vertical sections) in combination with data published by other researchers constitute the basis for handling these issues.

More often than not, researchers engaged in research on the geology of the region placed more emphasis in their publications on problems of magmatism, stratigraphy, petrology, geochemistry, geochronology, isotope geochemistry and ore genesis. Questions related to the geodynamics of the Ulkan trough were considered only in general terms and in a fragmented manner. The aim of this study is to systematise, synthesise and interpret geological, geochronological, geochemical and geophysical data on the volcano-plutonic and sedimentary formations of the Ulkan trough and its surrounding structures to address the following issues: (1) the role and place of magmatic complexes and volcanic-sedimentary sequences in the evolution history of the Ulkan paleorift structure and the character of relationships between various types of deposits and igneous rocks; (2) analysis of structural features controlling localization of the paleorift system and deposits of rare metals and rare earths, uranium and gold associated with the system; (3) stages and phases in the paleorift structure and development; (4) possible sources of igneous rocks and geodynamic settings for the formation of the volcano-plutonic association, as well as rare metal and rare earth deposits; and (5) correlation between anorogenic intraplate magmatism during the late Paleoproterozoic in the Siberian craton and other early Precambrian cratons. 


\section{General Geology and Previous Studies}

The development of the south-eastern margin of the Siberian in the Paleoproterozoic was marked by a number of spectacular endogenous and tectonic events resulted in the initiation of the Ulkan-Bilyakchan volcano-plutonic belt as long as $750 \mathrm{~km}[12,20,23]$. Extension processes were widely developed in the Late Paleoproterozoic, the earliest of them being accompanied by the accumulation of sedimentaryvolcanogenic thick sequences of rocks of the Ulkan and Nel'bachan Groups - Ulkan and Bilyakchan grabens, respectively. Emplacement of granitoid intrusions and swarms of mafic dykes is related to the most recent stretch processes. Structural and geological data, petro-geochemical characteristics of basaltoids found in sections of the Groups, their association with coarse clastic-terrigenous rocks suggest that these rocks are of a rift-related intracontinental nature $[12,18]$. The well exposed south-western branch of the Ulkan-Bilyakchan belt, i.e. the Ulkan graben (trough), has received the most study by us $[4,5,12,16,17,21]$. A-type granites bearing ample evidence of being post-kinematic are of widespread occurrence in the graben and within structures surrounding it [23]. They emplaced after the formation of the key mapped structures and were not subjected to regional metamorphism and folding thereafter.

The Ulkan sedimentary-volcanogenic trough (graben) occurs on the eastern edge of the AldanStanovoy shield in the upper reaches of Uchur, Ulkan and Maimakan (Fig. 1). It is confined to the wide near-EW-striking fault zone in the area controlled by structures of the Stanovoy suture zone, i.e. Pristanovoy collision belt [20]. The Ulkan trough is at least $75 \mathrm{~km}$ wide and $200 \mathrm{~km}$ long. The trough is sharply asymmetrical. Its axis, along which the major amount of differential sudsidence occurred, is shifted to its southern side coinciding with the South Uchur fault. The northern part of the trough is buried under the superimposed Uchur depression of Mesoproterozoic age. On the east, it is overlain by Cretaceous effusive rocks of the Okhotsk-Chukotka belt. The EW-trending gravity low corresponds to the Ulkan depression, whose centre falls on the Ulkan massif of granitoids [12]. The main tectonic elements controlling the trough position in the structure of the basement of the south-eastern Siberian platform are zones of the South Uchur and North Uchur deep faults which together with the northwestern Uchur-Elgete and south-western Ukikan faults of regional extent were important magma-feeding structures and controlled the position of volcanic centres and rock bodies.

According to the gravity survey data, these lineaments appear as gravity steps in the gravity field, which separate zones with anomalies differing in magnitude, shape and sign. The sedimentaryvolcanogenic Ulkan Group, infilling the trough of the same name, is the stratotype of the Upper Karelian in Eastern Siberia and the Far East of Russia and is recognized as the Ulkanian on the regional scale [12, 21]. Rocks of the Ulkan Group rest with sharp angular unconformity on the Archean crystalline basement of different blocks of the Aldan-Stanovoy shield and on their weathering crust and in turn are overlain by lower Mesoproterozoic deposits of the Siberian Platform cover [12, 16]. Intrusions of the Gekunda Complex gabbroid, the Ulkan Complex granitoid and the Maimakan Complex gabbrodolerite are associated with sedimentary-volcanogenic rocks of this Group.

A lot was published on rocks of the Ulkan trough [9, 12, 22, 27 and others]. Igneous rocks are divided into five complexes (rock associations): Ulkachan trachybasalt, Gekunda leucogabbro-dolerite, Elgete basalt-trachyrhyolite, Ulkan alkaline-leucogranite, and Maimakan gabbro-dolerite. A.M. Larin (2011) considers this cogenetic association of subalkaline-alkaline granites and subalkaline acidic and basic effusive rocks as A-type anorogenic granites of the Ulkan voncano-plutonic complex (VPC). All rocks of the VPC show high and very high contents of most of the incompatible elements [12, 23, 27].

The Ulkan group comprises three formations of red-bed rocks (Fig.2): Toporikan, Ulkachan and Elgete totalling over $3 \mathrm{~km}$ in thickness $[9,12]$. The Toporikan Formation $(200 \mathrm{~m})$ is exclusively made up of highly mature quartz and arkose-quartz sandstone deposited in shallow marine environment with coarse topography. The Ulkachan Formation $(750 \mathrm{~m})$ is presented by trachybasalt with interlayers of sandstone, tuffite and tuff siltstone. 


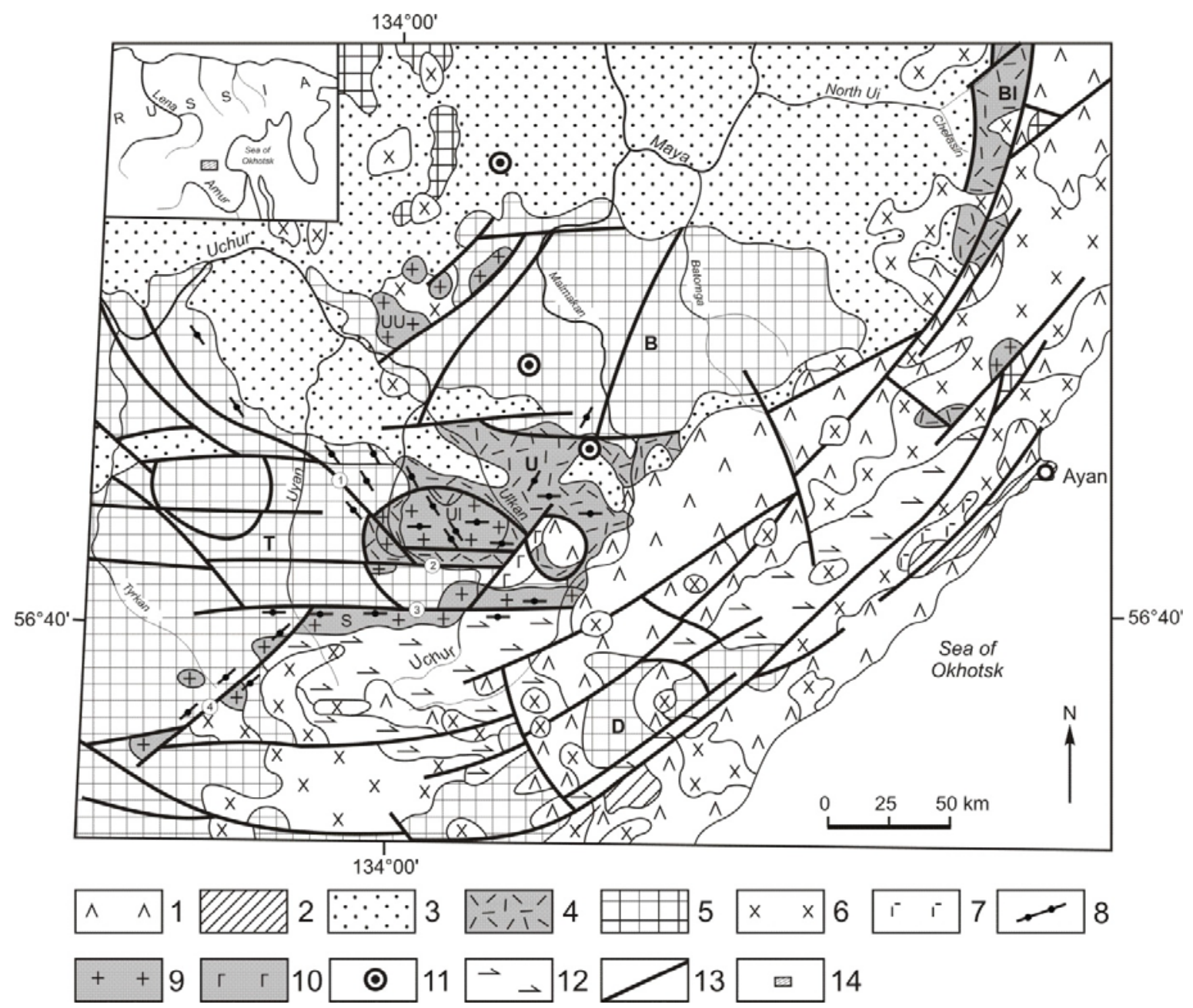

Figure 1. Geological scheme of southeastern margin of the Siberian Platform [12]. (1) Cretaceous volcanics of Okhotsk-Chukotka volcanic belt; (2) Paleozoic terrigenous and carbonate sequences of Ayan-Shevli Pericratonic Trough; (3) Cambrian-Mesoproterozoic volcanic-sedimentary and terrigenous-carbonate rocks of Uchur-Maya Plate; (4) Paleoproterozoic Ulkan (U) and Bilyakchan (Bl) volcanic-sedimentary troughs; (5) Archean crystalline rocks of Siberian Platform basement: Batomga (B), Tyrkan (T), and Dzhugdzhur (D) blocks; (6) Cretaceous granitoid plutons; (7) Paleozoic gabbroic rocks; (8-11) Paleoproterozoic intrusions: (8) basic dikes of the Maimakan Complex, (9) granitic rocks of Ulkan Complex, (10) gabbroic rocks of Gekundan Complex, (11) ultramafic rocks of Konder Complex; (12) anorthosite of Old Dzhugdzur Complex; (13) fault; (14) studied area (inset). Faults (numbers in circles): 1, Uchur-Elgetei; 2, North Uchur; 3, South Uchur; 4, Ukikan. Plutons (letters in figure): Ul, Ulkan; S, South Uchur; UU, Upper Ugayan.

The Elgete Formation $(2130 \mathrm{~m})$ is formed of effusives, ignimbrites and tuffs of the sheet facies with rare interbeds of sandstone. Subvolcanic, vent and extrusive facies are also characteristic of it. Trachyrhyolite, trachyrhyodacite and trachydacite are mostly present in the section of the Elgete Formation, basaltoids constituting not more than $20 \%$ of the Formation and comendite and pantellerite occurring only in the upper part of the section. The age of Elgete trachyrhyolites is estimated to be $1722 \pm 6 \mathrm{Ma}$ (U-Pb method on zircons $[23,29]$ ) and that of trachyrhyodacite $1732 \pm 4 \mathrm{Ma}$ (U-Pb method on zircons $[4,5])$. The Elgete Formation rests with angular unconformity either on the Ulkachan or Toporikan Formations and beyond their occurrence it overlies the crystalline basement. Trachydacite lava- breccias of the Formation basal levels contain boulders and pebbles of underlying basalts and gabbroids, the former being of the Ulkachan Formation and the latter of the Gekunda Complex. These data indicate a break in volcanism in post-Ulkachan - pre-Elgete time, which was accompanied by the 
upwarping of the territory where the Ulkan paleostructure occurs. During this time, intrusions of Gekunda gabbroids reached the surface where they were exposed to weathering and washing-out [12].

Granitoids, as part of the Ulkan VPC, form two large (Ulkan and South Uchur) and several mid-size massifs as well as smaller bodies that outcrop in different parts of the Ulkan trough and within flanking structures. Location of Ulkan intrusions is clearly controlled by fault tectonics; a combination of nearEW-, NW- and NE-trending faults and tectonically weakened zones determines their distribution and geometry [12]. According to the airborne geophysical survey data, granitoids of the Ulkan Complex stands out among other rocks in the geophysical field as having higher concentrations of radioactive elements, especially the Ulkan Massif. It is the massif with which all the known deposits and occurrences of rare and rare-earth metals of the region are spatially and genetically related.

The Ulkan Massif, which is $42 \mathrm{~km}$ long and at least $26 \mathrm{~km}$ wide, occurs in the central part of the graben of the same name. It is characterised by a large number of xenoliths which appear as roof pendants of host rocks [12]. The structure of the massif comprises three intrusive phases. Rocks of the first phase are mainly coarse-grained biotite subalkaline granites. Rocks of higher basicity are characteristically present in the zones where hybridism is developed. The second phase is represented by fine-grained biotite subalkaline leucogranite, and the third one by alkali granite and alkali quartz syenite. Dikes ranging in composition from lamprophyre to comendite and alkali granite pegmatite, zones and fields of rare-earth and rare metal alkali metasomatites and bodies of alkali hydrothermalites are associated with bodies of alkali granite. Uranium-lead dating on zircons from granites of the massif [23, 29] yielded the following ages: 1st phase - 1721 $\pm 1 \mathrm{Ma}$, 2nd phase - 1716 $\pm 2.5 \mathrm{Ma}$, and 3rd phase $1705 \pm 5$ Ma. According to A.N. Didenko et al. [4, 5], the age of the 1st and 3rd phase granites (U-Pb zircon method) from this massif is $1729.7 \pm 1.9 \mathrm{Ma}$ and $1724.7 \pm 3.6 \mathrm{Ma}$, respectively.

The Ulkan massif is an area of the widespread Paleoproterozoic intraplate alkali-granite magmatism and concentration of endogenous ore deposits unique in dimensions and diversity (Be, Ta, Nb, Zr, TRy, TRce, U, Au, Li, Sn, W, Mo, Ti and (Pt)) [14, 15, 18, 26, 28]. Rare metal and rare earth deposits are genetically associated with alkaline granites and their derivatives. Almost all of them occur in exocontact zones of the Nygvagansky alkaline granite stock located in the central part of the Ulkan massif of subalkaline granitoids. The most important elements in these deposits are Be, Ta, Nb and TR. The U-Pb and Pb-Pb ages of REM and REE deposits ranging from $1720 \pm 23$ to $1670 \pm 70$ Ma closely match the age of alkaline granites $[11,15]$.

The 1727 \pm 6 Ma South Uchur Massif (U-Pb zircon method) [29] is an EW-trending fairly large (1500 km2) fissure-type body. Along the southern boundary, it is in eruptive contact with the Archean anorthosites of the Dzhugdzhur Massif; the northern boundary is of a tectonic nature. The dominant rock is amphibole-biotite subalkaline granites occasionally with rapakivi structures; rocks characterised by higher basicity, which are typical of zones where processes of hybridism and assimilation of xenoliths of host rocks are developed, are rare. This massif is confined to the Stanovoy suture zone (South Uchur fault). A series of southerly occurring small bodies of granitoids of the Ulkan Complex is localised in the Dzhugdzhur Block of the Pristanovoy Belt of high-pressure granulite interpreted as a Paleoproterozoic zone of collision (over $1.9 \mathrm{Ga}$ ) [10, 20].

Granitoids of varying composition in the Ulkan Complex were derived from high-temperature dry magmas in the shallow environment (about $4 \mathrm{~km}$ ) under strongly reducing conditions with a high content of alkalis, most of LIL and HFS elements, fluorine, and chlorine [23, 27]. Iron-rich and magnesium-iron silicates are characteristically present in these granites, and alkali amphiboles and pyroxenes are characteristic of alkaline granites.

The Maimakan Complex of gabbro-dolerite dykes completes the late Paleoproterozoic magmatism in the Ulkan paleostructure. Dykes are in distinct eruptive contacts with granites of the Ulkan and South Uchur Massifs and are overlain by Mesoproterozoic sedimentary strata of rocks of the Uyan Group [12]. Uranium-lead dating of zircons from the gabbro-dolerite dyke intruding granites of the Ulkan Massif yielded $1707 \pm 32 \mathrm{Ma}$ [17]. These dikes are ore-controlling for uranium-rare earth and uraniummolybdenum mineralisation. Geochronological studies on ores from uranium and gold-molybdenum deposits (U-Pb, Pb-Pb, Rb-Sr and K-Ar methods) yielded their mid-Mesoproterozoic age of formation within the 1320-1150Ma bracket [11, 12]. These deposits have a wider area of distribution and are localized both in granites of the massif and sedimentary-volcanic rocks of the Ulkan trough, which could act as source rocks for ore deposits. 


\begin{tabular}{|c|c|c|c|c|c|c|}
\hline \multicolumn{3}{|c|}{$\begin{array}{l}\text { Genoral } \\
\text { stratigraphic } \\
\text { unils }\end{array}$} & Column & $\mid \begin{array}{l}\text { The thicknest } \\
\text { sampling } \\
\text { im and } \\
\text { localtiog }\end{array}$ & \multicolumn{2}{|r|}{ Lithological characteristics (the sample numbers are in parentheses) } \\
\hline \multirow{7}{*}{\multicolumn{2}{|c|}{ 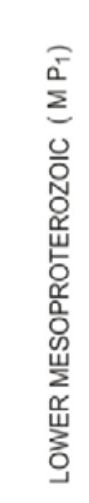 }} & \multirow{3}{*}{ 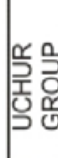 } & & $110-360$ & \multicolumn{2}{|r|}{ Ennin Formation: sandstones, siltstones, mudstones, and dolomites } \\
\hline & & & 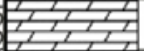 & $30-350$ & \multicolumn{2}{|r|}{ Omakhta Formation: dolomites, siltstones, and mudstones } \\
\hline & & & 等, & $140-360$ & \multicolumn{2}{|r|}{ Gonam Formation: sandstones, siltstones, dolomites, mudstones. } \\
\hline & & & $\frac{1}{2}$ & $70-180$ & \multicolumn{2}{|r|}{ Adargai Formation: sandstones, siltstones, and dolomites } \\
\hline & & 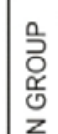 & 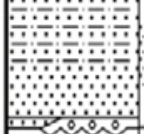 & $200-950$ & \multicolumn{2}{|r|}{$\begin{array}{l}\text { Konkuli Formation: sandstones, silty sandstones, conglomerates, and } \\
\text { gravelstones }\end{array}$} \\
\hline & & $\frac{5}{5}$ & $\mid \frac{-\Delta}{--\Delta} \Delta$ & $280-350$ & \multirow{2}{*}{ 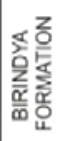 } & $\begin{array}{l}\text { Upper Birindya Subformation: subalkaline olivine basalts and } \\
\text { leucobasalts, and sandstones }\end{array}$ \\
\hline & & & & $130-280$ & & Lower Birindya Subformation: sandstones, conglomerates, and basalts \\
\hline \multirow{5}{*}{ 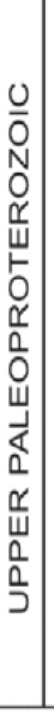 } & \multirow{5}{*}{ 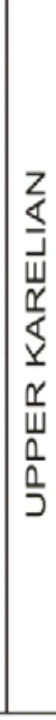 } & \multirow{5}{*}{ 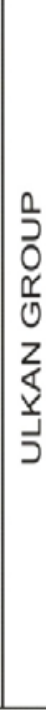 } & & 740 & \multirow{3}{*}{$\begin{array}{l}z \\
0 \\
- \\
\vdash \\
\varangle \\
\Sigma \\
\alpha \\
0 \\
\llcorner \\
- \\
w \\
\vdash \\
w \\
0 \\
- \\
\omega\end{array}$} & $\begin{array}{l}\text { Upper Elgetei Subformation: trachyrhyolites, trachyrhyodacites, } \\
\text { alkaline trachydacites, and their gnimbrites } \\
\text { and tuffs, trachybasalts }\end{array}$ \\
\hline & & & & 750 & & $\begin{array}{l}\text { Middle Elgetei Formation: trachyrhyodacites, } \\
\text { spotty trachyrhyolites and their tuffs and ignimbrites, } \\
\text { trachybasalts, basalts, intercalations of sandstones, } \\
\text { conglomerates, and siltstones. }\end{array}$ \\
\hline & & & $i_{+}^{+}$ & 640 & & $\begin{array}{l}\text { Lower Elgetei Subformation: trachyrhyodacites, trachydacites, } \\
\text { dacites, trachybasalts, basaltic andesites, } \\
\text { intercalations of sandstones, tuffites, tuffstones, and tuffaceous } \\
\text { sandstones }\end{array}$ \\
\hline & & & 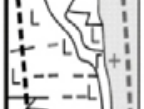 & 750 & & $\begin{array}{l}\text { Ulkachan formation - trachybasalts, basalts, } \\
\text { intercalations of sandstones, tuffaceous siltstones, tuffites, tuffstones, } \\
\text { and conglomerates }\end{array}$ \\
\hline & & & $\therefore$ & $100-200$ & & $\begin{array}{l}\text { Toporikan Formation: sandstones with lenses of gravelstones, } \\
\text { tuffstones, and conglomerates }\end{array}$ \\
\hline \multicolumn{3}{|c|}{ ARCHEAN } & 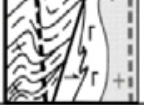 & $>1000$ & & $\begin{array}{l}\text { Undivided Archean complexes: gneisses, crystalline schists, granit } \\
\text { gneisses, and metagabbroids with anorthosite intrusions }\end{array}$ \\
\hline
\end{tabular}

Figure 2. Stratigraphy and magmatism of Ulkan-Uchur district [12]. (1) Archean gneisses and crystalline schists; $(2,3)$ Late Paleoproterozoic intrusive rocks: (2) basic dikes of Maimakan Complex, (3a) granitic rocks of Ulkan Complex; (3b) gabbroic rocks of Gekundan Complex; $(4,5)$ Archean metamorphic rocks: (4) metagabbroids, (5) metagranites and granite gneisses; (6, 7) uncon-formities: (6) stratigraphic, (7) angular; (8) weathering crust; (9) fault.

As for the metallogeny, the Ulkan trough as a unique area hosting REM, REE, uranium and precious metal mineralisation is one of the most promising ore targets of Eastern Siberia and the Far East of Russia [14, 15].

According to isotope-geochronological studies on zircons from the Early Precambrian crystalline basement rocks in the southern flanking of the Ulkan trough carried out by V.A. Guryanov with coauthors [16], the Ulkan event shows a contrast image in zircon geochemical systems $(1769 \pm 9-1690 \pm 14$ Ma.) - regional-scale late Paleoproterozoic stage of intense tectonothermal reworking of crystalline basement rocks of the south-eastern Siberian Platform, which is related to the development of the Ulkan, Bilyakchan and other proto-aulacogens; emplacement of voluminous intrusions of normal and alkaline granites, syenite, monzonite of the Ulkan, Nudymi and other complexes. Komatiite dike swarms and 
rare subalkaline granitic intrusions of the Ulkan complex can be traced on the southern periphery of the Ulkan trough among Archean granulites and anorthosites of the Dzhugdzhur block [12, 19]. Economic sulfide copper-nickel mineralisation with platinum-group elements (PGE) is found to be komatiiteassociated. Estimates for the age of komattite are $1690+14,1700+12,1710+10,1720+12$ and $1730+15$ Ma (Kun-Manie Cu-Ni deposit; U-Pb SHRIMP age on zircons, Centre of Isotopic Research, VSEGEI, St. Petersburg, [19]). It appears evident that in the south-eastern part of the Aldan-Stanovoy shield there occurred tectonic and metamorphic events at 1.77 - $1.70 \mathrm{Ga}$ accompanied by intense metamorphism (up to granulite facies) of Archean anorthosites of the Old Dzhugdzhur complex and enclosing rocks [13, 16, 32] and intense granitoid magmatism. According to [16], late Paleoproterozoic rifting processes are most probably responsible for originating new tectonic structures and reactivating old structures. The abovenamed researchers relate this event to the final stage of cratonization of the Aldan-Stanovoy crustal block, with the completion of which it entered the platform stage.

The lowermost strata of the Lower Mesoproterozoic of the Siberian Platform (Uchur depression), which rest on volcanics of the Elgete Formation, are exposed on the north of the Ulkan paleorift structure [21]. The Lower Mesoproterozoic here is represented by volcanogenic-sedimentary and carbonate-terrigenous rocks of the Uyan and Uchur Groups (Fig. 2). Basal levels of the Uyan Group represented by conglomerates with boulders and pebbles of quartz and Elgete volcanics occur with angular unconformity on ferruginous-clay-hydromicaceous weathering crust of effusives in different parts of the section of the Elgete Formation. The $\mathrm{Rb}-\mathrm{Sr}$ isochron age of the authigenic adular from the weathering crust is $1670 \pm 40 \mathrm{Ma}$ [21]. The early Mesoproterozoic is taken as the age of the Uyan Group based on the fact of its being overlain by the Gonam Formation of the Uchur Group with a K-Ar glauconite date of 1520-1450 Ma and early Mesoproterozoic oncolites and stromatolites present in its structure [21].

\section{Structural Features of Locating the Ulkan Paleorift System}

Analysis of geological and geophysical data indicates that the Ulkan volcano-plutonic structure should be considered as a complex paleorift system consisting of three branches or "arms" (Fig. 1). The central near-EW-trending branch of the system is the Ulkan graben infilled by bimodal volcanics and sediments of the Ulkan Group and comagmatic granitoids and gabbroids. The Uchur-Elgete and Ukikan tectonically weakened zones, within which are mapped small granitoid massifs of the Ulkan Complex and fields of effusive rocks of the Elgete Formation, branch off the central part of the graben in northwesterly and south-westerly directions [12, 17]. Moreover, swarms of basite dykes of the Maimakan Complex are confined to these three zones. Striking of dykes and dyke swarms follow the orientation of these structural elements. In other words, the Ulkan paleostructure has a three-armed geometry. Fault zones controlling basite dykes are at 90 to 135 degree angles thus creating a structural pattern close to a triple junction of zones of extension typical of regions of oceanic spreading and continental rifting (the Afar Triangle). The three-armed distribution pattern of the Maimakan Complex dykes suggests that its formation most probably involves the rise of a mantle diapir (plume). Triple junction, as a rule, is indicative of intense rifting related to hotspot activity [1]. Such a hotspot-type diapir could mostly likely be the multiphase Ulkan alkaline-leucogranite batholith.

The area where swarms of basite dykes intersect is in the central part of the Ulkan granitoid massif (Fig. 1). According to geologic data, this area where dyke swarms converge and join coincides with the region of maximum manifestation of alkaline granite magmatism (Nygvagan alkaline granite massif) and alkaline metasomatism [17]. Most likely it was the epicentre of the hot spot, a distinctive zone of most intense impact of mantle fluids along the periphery of which there occur all the known numerous ore occurrences and deposits of rare metals (Be, $\mathrm{Ta}, \mathrm{Nb}, \mathrm{Zr}, \mathrm{Li}, \mathrm{Sn}$ ), rare earths, uranium, and thorium of the Ulkan ore district $[12,22,26]$.

In tectonic terms, it is important to note that deposits and occurrences of rare metals and rare earths, as well as uranium, gold and platinum, are confined to the zone of triple junction of the Ulkan graben and two arms (Uchur-Elgete and Ukikan), which appears as a domain of intense intraplate alkalinegranitic magmatism and concentration of endogenous ore deposits unique in dimensions and diversity (Be, Ta, Nb, Zr, TRy, TRce, U, Au, F, Li, Sn, W, Mo, Ti and (Pt)) [12, 14, 15, 18, 28, 26], whose age ranges from 1.720 to $1.67 \mathrm{Ga}[12,15]$. A distinctive pattern of localisation - an inherent characteristic of 
the deposits formed in this time interval referred to above, together with geochemical and isotopicgeochronological data on Ulkan granitoids, allows us to relate their origin to the activity of a late Paleoproterozoic (1.77-1.70 Ga) mantle plume or hot spot.

\section{Specific Features of the Ulkan Paleorift Development}

A number of specific features are recognised in the structure and the history of the Ulkan paleorift, which are inherent in most present-day continental rift structures. It is characterised by the extensive development of pre-rift planation surfaces formed by denudation that belong to peneplains and are geomorphic expression of the regional angular unconformity recorded by the areal weathering crusts of the basement rocks (Fig. 2) [12]. As in the Rhine graben, the formation of bimodal differentiated series of volcanics in the Ulkan structure is related to the central-type volcanic activity and is due to the presence of intermediate volcanic centres. The preceding fissure volcanism is related to zones of extension. A sub-alkaline tendency is typical in the early stages of rifting and an alkaline one in the closing stages. The observed clear contrast (bimodality) of the Elgete Formation of the Ulkan paleorift is in general inherent in the Nelbachan Group of the Bilyakchan graben, i.e. the north-eastern branch of the Ulkan-Bilyakchan volcano-plutonic belt, and is represented by basalt-trachyrhyolite and trachybasalt-rhyolite rock associations [12]. In both cases, there is a large gap in time between the age of the basement and the beginning of rifting.

Five phases of changes are recognised in paleotectonic movements, deformations and, accordingly, restructuring based on the presence of gaps and unconformities in the section of the Ulkan Group of the paleorift of the same name, which is evidenced by changes in the type, character and thickness of constituting rock sequences, by the manifestation of different magmatism at different stages in the paleorift structure development. In accordance with this the following stages in the development of the Ulkan paleorift are recognised.

Stage 1. Stratigraphy of the Toporikan Formation deposits preserved in the Ulkan graben indicates that prior to the graben formation there was no dome as a precursor of rifting. The initial stage of the paleostructure formation was preceded by intensive displacement and faulting of the crystalline basement in the zones controlled by emerging near-EW-striking deep faults (North Uchur, South Uchur). Basement subsidence and early extensional fracturing resulted in the formation of embryonic shallowmarine basins. Sediment accumulation was controlled by listric faults and, judging by the presence of quartz in sandstone and the pre-Toporikan weathering crust below them, proceeded under coarse topography conditions of the uplifts flanking the basin.

Stage 2. A series of extended, linear graben structures, which triggered the initiation of the Ulkan graben, originated in the zones controlled by the near-EW-striking basement faulting. The Ulkachan trachybasalt volcanism as a result of fissure eruptions occurred in shallow-marine settings. Tensile stress was across the paleorift strike as judged from the trend of basite dykes and the dominant direction of lava flows. The presence of interlayers of conglomerates in the section of the Ulkachan Formation suggests that subsidence of the paleo-basin basement at certain stages gave way to basement uplifts. In Ulkachan time, this structure was a graben 70 to $75 \mathrm{~km}$ wide southerly plunging in a stepwise manner. Emplacement of intrusions of Gekunda gabbroids within the zone controlled by North Uchur and South Uchur deep faults completed volcanism of this stage.

Stage 3. A break in volcanism and sedimentation that preceded the accumulation of thick sequences of rocks of the Elgete Formation resulted from the uplift of the territory where the Ulkachan paleo-basin occurs. The pre-Elgete uplifting was accompanied by folding, intensification of near-EW-trending old fault zones and initiation of NE- and NW-trending new ones (Ukikan and Uchur-Elgete zones), and peneplanation of the dome [12]. The exposed intrusions of Gekunda gabbroids (from depths of 1-1.5 km) were subjected to erosion and washing-out. Boulders and pebbles of Gekunda gabbroids and Ulkachan basalts occur in the basal levels of the Elgete Formation. Given the erosion level of intrusions of the Gekunda Complex, volcanic accumulations in Ulkachan time were as thick as $2.0-2.5 \mathrm{~km}$.

Stage 4. On the whole, the following is typical of the Elgete Formation: continentality of its section, sub-alkaline, acidic and alkaline lavas, basic lavas interbedded with coarse-grained terrigenous rocks being subordinate [12]. Glauconite in sandstone in the lower part of the Formation is indicative of considerable depths in the Ulkan paleo-basin in the early stages of the Elgete volcanism [9, 21]. However, 
the occurrence of ignimbrite and the loss of terrigenous rock interbeds in the lower part of the Formation section evidence that there was intense uplifting of the paleo-basin territory in the late stages of its development. Owing to the basement faulting and the subsequent intensification of volcanism along faults as well as the emplacement of granitoid intrusions, it was at the Elgete period when the Ulkan paleorift structure developed a structural pattern reminiscent of a three-armed geometry of zones of extension. The multiphase Ulkan alkaline-leucogranite batholith was emplaced and evolved in the area where these arms join. A considerable extent of the batholith is bounded by a system of arcuate and ring faults allowing it to be interpreted as a diapir that caused upwarping. The Ulkan batholith was emplaced at a depth of about $4 \mathrm{~km}$ [27]. Accordingly, the Elgete Formation at that time was at least 6 $\mathrm{km}$ thick. Such upwarping of the rocks into a dome similar to the events in the East African Rift System was subsequently accompanied by erosion. Boulders and pebbles of the Elgete volcanics occur within the basal levels (down to 50-75 m) of the lower Mesoproterozoic of the Siberian platform cover $[12,21]$.

Basite dykes of the Maimakan Complex record a stage of stabilisation of the Ulkan three-armed paleorift system. Its tectonic instability was most likely due to the emptying of magma chambers and subsidence of the domal uplift and, as a result, intensification of deep foci of magmatism, formation and development of fissure swarms of faults accompanied by the intrusion of basite dykes along the arms of the paleorift system.

Five stages are recognised in the development of the Ulkan paleorift system, which based on a number of geodynamic features can be grouped into three major phases [18]. The first phase: processes of extension and subsidence of the Archean basement in the zone of near-EW-striking deep faults caused the emplacement and development of the near-EW-trending Ulkan graben; fissure volcanism was related to areas of extension (development according to the passive rifting model). The second phase: formation of the bimodal differentiated series of volcanics of the Elgete Formation is associated with the centraltype volcanic activity and is due to the presence of intermediate foci of magmatism. A strong thermal flow and rising of the Ulkan hotspot-type mantle diapir, which caused the upwarping of rocks into a dome, were characteristic of the geodynamic setting in Elgete time. The initiation of the three-armed intracontinental Ulkan paleorift system is related to this hotspot. This paleorift structure developed according to the active rifting model. The final phase: the emplacement of basite swarms of dykes of the Maimakan Complex is a stabilisation phase of the three-armed intracontinental Ulkan paleorift system.

\section{$5 \quad$ Sources and Geodynamic Settings of the Ulkan VPC Formation}

Data on the chemical composition and distribution of rare and rare earth elements in volcanics and granitoids of the Ulkan VPC and these data analysis are given in a number of publications [4, 12, 23 and others]. On classification diagrams, the plotted compositions of sub-alkaline and alkaline granites and volcanics of the Ulkan graben occur within the fields of the plotted compositions of rocks of the alkaline and alkali-lime series while on discrimination diagrams within the field of intra-plate granites. Granites and volcanics are extremely high in iron $(\mathrm{f}=0.75-1.00)$ and belong to the potassic and sodic series, rocks of the potassic series, that include sub-alkaline granites and most of the volcanics, being dominated by them. Among rocks of the sodic series there are alkaline granitoids as well as comendites and pantellerites. High values of the agpaitic index $(\mathrm{NK} / \mathrm{A}=0.96-1.57)$ are characteristic of alkaline rocks whereas for rocks of the potassic series this index is within $0.6-1$. 00. Granitoids of the Ulkan massif differ from granites of the South Uchur massif by higher Be, Nb, Ta, Li, Sn, TR, Rb, U and Th contents and depletion in Ва и Sr. Alkaline granitoids are highly enriched in most of the incompatible elements as well as Zn, Mn, F and precious metals [18]. Spider diagrams for these rocks are similar to those for typical anorogenic rare metal alkaline granites [4, 23].

Geochemical data and findings of the isotope-geochronological study on rocks of the Ulkan VPC are indicative of the OIB source for the alkaline (Na-series) granites and the essentially lithospheric source for sub-alkaline ( $\mathrm{K}$-series) granites $[12,23]$. Wide variations in $\mathrm{Ce} / \mathrm{Pb}$ ratios (from 4.3 to 23.4) suggest different relationship between mantle and crustal components in the sources of granitoids, its maximum values (18.6-23.6) in alkali granites evidencing that the mantle component is of considerable importance in their formation. The plotted compositions of these granites on the $\mathrm{Nb} / \mathrm{U}-\mathrm{Th} / \mathrm{Ta}$ diagram occur on the line of mixing of the continental crust and the mantle (OIB or MORB). According to A.M. Larin 
[23], the formation of anorogenic rocks of the Ulkan VPC in the intraplate settings was associated with mantle plume activity at $1.77-1.70 \mathrm{Ga}$ [16] and proceeded through mixing of two melts: essentially mantle and essentially crustal. The presence of komatiites associated with alkaline-granite magmatism of the same age $(1.73-1.70 \mathrm{Ga})$ is also indicative of the plume source $[18,19]$.

The authors of this work [17] have arrived at a similar conclusion when studying basite dykes of the Maimakan Complex, in the formation of which culminated the Late Paleoproterozoic anorogenic magmatism on the southeast of the Aldan-Stanovoy shield. Basites in this work are identified as moderately alkaline rocks that are transitional from tholeiitic to alkaline and belong to the mantle series of basalts of non-subduction settings. They are similar to intra-plate basalts and enriched in MOR basalts. The distribution of rare earths in basite dykes is similar to that in rocks of the tholeiitic and sub-alkaline series in zones of extension. Along with geologic data this suggests their formation in the setting of intracontinental stretching accompanied by rising of a mantle diapir. Analysis of spatial arrangement of dyke swarms within the Ulkan graben and its flanking structures shows that the area of swarms' convergence (junction) coincides with the area where alkali-granite magmatism and associated alkali metasomatism (Nygvagan massif of alkali granites) were greatest. Most likely, it was the epicentre of the hotspot or plume head.

A powerful heat flow and ascending mantle diapirs in the rear part of the south-eastern Siberian platform were characteristic of the geodynamic setting at the end of the late Paleoproterozoic [16]. The Ulkan alkali-leucogranite batholith $(750 \mathrm{sq} \mathrm{km})$, which hosts the Nygvagan massif of alkali granites (14 $\mathrm{sq} \mathrm{km}$ ) in its central part - the epicentre of the hotspot, is one of such hotspot-type diapirs. The initiation of the three-armed intracontinental system, i.e., the Ulkan-Bilyakchan volcano-plutonic belt, along the south-eastern margin of the Siberian platform is related to this type of hotspots. As noted earlier, a triple junction is indicative of intense rifting linked to hotspot activity. It is found that minerals of Archean rocks in the basement were thermally rearranged in the interval between 1.77 and $1.70 \mathrm{Ga}$ in the south-eastern Siberian platform [16]. At the same time, the late Paleoproterozoic (Ulkan) stage of intense tectonothermal recycling of rocks of different blocks in the south-eastern part of the Aldan-Stanovoy shield (1765 $\pm 9-1690 \pm 14$ Ma, SHRIMP-II [16]) is most clearly reflected in geochemical systems of zircons. The initiation and development of the Ulkan and other proto-aulacogens, emplacement of voluminous intrusions of syenites, monzonites, sub-alkaline and alkaline granites of the Ulkan and other complexes, sills and dykes of komatiites are related to this regionally manifested stage. All this evidences that rising of the hot mantle matter which triggered the thermal rearrangement of minerals in different rocks of the basement occurred between 1.77 and $1.70 \mathrm{Ga}$. Another significant feature is that at the same time (at about $1.73 \mathrm{Ga}$ ) there occurred also a thermal rearrangement of $\mathrm{K}-\mathrm{Ar}$, $\mathrm{Rb}-\mathrm{Sr}$ and U-Pb isotopic systematics of certain minerals from the south-eastern Siberian Platform [12, 16]. The thermal event has a much wider range than the magmatic event of that time.

In the interval between $1.77(1.75)$ and $1.70 \mathrm{Ga}$, anorogenic magmatism is clearly recorded along the south-eastern and south-western flanking of the Siberian platform of the North Asian Craton, in the North American platform (Nueltin, M `Clure Bay and Cap Farewell massifs) and in northern China. In the North China Craton, there are several small massifs of rapakivi granites (1716 $\pm 31 \mathrm{Ma}$, Shachang Complex), bimodal volcanics of the Dahongyu Formation and swarms of dolerite dykes with an age of c. $1.70 \mathrm{Ga}[30,31,33]$, which are part of the Paleo-Mesoproterozoic Central Rift System (YanshanTaihangshan aulacogen). The system which occurs in the central part of the craton has a three-armed structure and is superimposed on the Trans-North China Belt (c. 1.9 Ga). The Langshan-Bayan Obo Rift System, whose basalts in the lower part of the section have an age of $1.73 \mathrm{Ga}$, extends along the northern edge of the craton [31]. According to Chinese geologists [33, 34], the rapakivi-granite magmatism is anorogenic and is linked to the mantle plume activity.

Thus, the intraplate tectonic event manifested as rifting accompanied by extruding of bimodal volcanics and emplacement of alkali-leucogranite massifs occurred in the North Asian and North China Cratons in the interval between 1.77-1.70 Ga. This magmatism in both cases occurred 150-200 Ma after the completion of orogenic processes in hosting fold structures of the Pristanovoy as well as the TransNorth China Belts. Intense rifting against the background of upwarping of the rocks into a dome, Fe-Ti basalts that are transitional from tholeiitic to alkaline, the occurrence of alkali granites that have an OIB-type mantle source $[17,23]$ - all point to the plume nature of two closely related types of intraplate magmatism in the Ulkan graben of the Ulkan-Bilyakchan volcano-plutonic belt and the Yanshan- 
Taihangshan aulacogen. It should be noted that at that time in the majority of palinspastic reconstructions the North China Craton was placed in the immediate vicinity of Siberia [3].

\section{Conclusions}

Five stages are recognised in the development of the Ulkan paleorift system, which can be grouped into three major phases based on a number of geodynamic features. At the first stage, processes of extension and downwarping as a result of the Archean basement faulting triggered the initiation and development of the near-EW-trending Ulkan graben. At the second stage, a powerful heat flow and the ascending hotspot-type mantle diapir that triggered the formation of the domal uplift were characteristic of the geodynamic setting of the bimodal differentiated series formation related to the central-type volcanic activity. The initiation of the three-armed intra-continental rift system is linked to this hotspot. Emplacement of basite dykes of the Maimakan Comples records the stage of its stabilisation as the final stage in the development of this structure.

Thus, the intraplate tectonic event expressed as rifting accompanied by eruption of bimodal volcanic rocks and emplacement of A-type granite plutons occurred on the southeast of the Siberian Platform in the 1.77 - $1.70 \mathrm{Ga}$ interval. This magmatism started 150 - $200 \mathrm{Ma}$ after the orogenic events in the Pristanovaya collision zone. Active rifting in response to doming of the crust, Fe-Ti basalts intermediate in composition between lavas of alkaline and tholeiitic series with Fenner differentiation trend, the presence of high-temperature komatiite-type volcanic rocks, the presence of alkaline granites and granosyenites with OIB-type mantle source - all this indicates a plume nature of the intraplate magmatism. The presence of komatiites associated with the alkaline-granite magmatism is also in favour of the plume source.

The Ulkan paleorift structure has features of a three-armed geometry indicative of intense rifting due to hotspot activity. Volcanics and granitoids of the Ulkan Complex were formed in the intra-continental environment of extension accompanied by rising of the mantle plume. The Ulkan alkali-leucogranite massif was such a hotspot-type diapir. The area of convergence of basite dyke swarms coinciding with the area of development of alkali-granite magmatism and alkali metasomatism at the centre of the massif was a likely epicentre of the hotspot. Granites and basites of the Ulkan VPC were formed through mixing of two different melts: essentially crustal and essentially mantle.

In terms of tectonics, the triple junction of the Ulkan graben and two arms (Uchur-Elgete and Ukikan) appears as a zone of intense intraplate alkaline-granitic magmatism during late Paleoproterozoic time and concentration of ore deposits aged between 1.72 and $1.67 \mathrm{Ga}$, that are unique in dimensions and diversity (Be, Ta, Nb, Zr, TRy, TRce, U, Au, Li, Sn, W, Mo, Ti and (Pt)). Rare-metal and rare earth deposits are in essence the product of rare metal-alkaline-granitic magmatism and associated with the evolution of the mantle source related to plume activity.

Formation of uranium-rare earth, molybdenum-uranium and gold-molybdenum deposits is most probably controlled by the processes of mid-Mesoproterozoic rejuvenation of the region and rocks of the Ulkan volcano-plutonic association.

Rising of the mantle diarpir in the rear part of the south-eastern Siberian platform was accompanied by a strong heat flow and hence tectonothermal recycling of rocks of different blocks in the southeastern part of the Aldan shield.

Anorogenic magmatism of this type is clearly recorded in the interval between $1.77-1.70 \mathrm{Ga}$ along the south-eastern and south-western flanking of the Siberian platform, in the North American platform and northern China. This magmatism occurred 150-200 Ma after the completion of orogenic processes in hosting fold structures of collision belts.

The study was performed as part of the State Assignment of Kosygin Institute of Tectonics and Geophysics, Far East Branch, Russian Academy of Sciences.

\section{References}

1. K. C. Burke and J. F. Dewey, "Plume generated triple Junktioskey indicators in applying plate tectonics to old rocks", J. Geol., vol. 81, pp. 406-433, 1973. 
2. B. Bonin, "A-type granites and related rocks: evolution of a concept, problems and prospects", Lithos, vol. 97, pp. $1-29,2007$.

3. K. C. Condie, "Breakup of the Paleoproterozoic Supercontinent", Gondvana Research, vol. 5, pp. 41-43, 2002.

4. A. N. Didenko, V. A. Guryanov, A. Yu. Peskov, A. N. Perestoronin, D. V. Avdeev, Ye. V. Bibikova, T. I. Kirnozova, M. M. Fugzan, "Geochemistry and geochronology of Proterozoic magmatic rocks of the Ulkan trough (new evidence)", Tikhookeanskaya Geologiya, vol. 29, no. 5, pp. 44-69, 2010. (in Russian).

5. A. N. Didenko, V. A. Guryanov, A. Yu. Peskov, A. N. Perestoronin, A. V. Kosynkin, "Paleomagnetism of the Ulkan trough (SE of the Siberian craton)", Tikhookeanskaya Geologiya, vol. 32, no. 1, pp. 31-53, 2013. (in Russian).

6. T. V. Donskaya, D. P. Gladkochub, V. P. Kovach, A. M. Mazukabzov, "Petrogenesis of Early proterozoic postcollision granitoids on the south of the Siberian Craton", Petrologiya, vol. 13, no. 3, pp. 253-279, 2005. (in Russian).

7. G. N. Eby, "The A-type granitoids: a review of their occurrence and chemical characteristics and speculations on their petrogenesis", Lithos, vol. 26, pp. 115-134, 1990.

8. R. E. Ernst, Large Igneous Provinces. Cambridge University press, 2014.

9. Yu. N. Gamaleya, "Formation analysis and history of the south-eastern Siberian Platform in the Precambrian", Geotektonika, no. 6, pp. 34-45, 1968. (in Russian).

10. V. A. Glebovitsky, V. Ya. Khil'tova, I. K. Kozakov, "Tectonic structure of the Siberian Craton: interpretation of geological, geophysical, geochronological, and isotopic-chronological data", Geotektonika, no. 1, pp. 12-26, 2008. (in Russian).

11. M. V. Goroschko, Yu. Ph. Malyshev, V. E. Kirillov, Uranium Metallogeny of the Russian Far East. Moscow: Nauka, 2006. (in Russian).

12. V. A. Guryanov, Geology and metallogeny of the Ulkan area (Aldan - Stanovoy Shield). Vladivostok: Dal`nauka, 2007. (in Russian).

13. V. A. Guryanov, L. P. Karsakov, "Lower Precambrian Stratigraphy of the southeastern Siberian platform", in Lower Precambrian Stratigraphy of the Russian Far East. Vladivostok, Far Eastern Branch of the USSR Academy of Sciences, 1990. pp. 18-30. (in Russian).

14. V. A. Guryanov, M. V. Goroshko, "Rare metals and rare earths of the Ulkan ore district", in The strategy of management and development of the mineral resource base of rare metals in Russia in 21st century. Proceedings of the International Symposium. Moscow, 1998. pp. 57-59. (in Russian).

15. V. A. Guryanov, M. V. Goroshko, "The main features of the Precambrian metallogeny of the Ulkan district", Tikhookeanskaya Geologiya, vol. 24, no. 6, pp. 101-128, 2005. (in Russian).

16. V. A. Guryanov, G. V. Roganov, V. N. Zelepugin, M. I. Rozinov and T. E. Saltykova, "Isotopic Geochronological Studies of Zircons from the Early Precambrian Rocks of the Southeastern Aldan - Stanovoy shield: new results, their geological interpretation", Tikhookeanskaya Geologiya, vol. 31, no. 2. pp. 3-21, 2012. (in Russian).

17. V. A. Guryanov, A. N. Perestoronin, A. N. Didenko, A. Yu. Peskov and A. V. Kosynkin, "Late Paleoproterozoic Basic Dikes in the Ulkan - Uchur District, Eastern - Aldan - Stanovoy Shield: Structural Position, Composition, and Formation Setting", Geotectonics, vol. 47, no. 4, pp. 279-290, 2013. (in Russian).

18. V. A. Guryanov, A. Yu. Peskov, "Ulkan paleorift structure in the South-Eastern environs of the Siberian Platform: Age, Conditions, Geodynamic Setting and Metallogeny", in. Large Igneous Provinces, Mantle Plumes and Metallogeny in the Earth's History. Irkutsk: Publishing House of V. B. Sochava Institute of Geography SB RAS, 2015, pp. 53-54. (in Russian).

19. V. A. Guryanov, V. S. Prikhod'ko, L. L. Petukhova, A. Yu. Peskov, "Geochimal features of mafic-ultramafic dikes of the Kun-Manie ore field: geodynamic aspect (East Stanovik)", in Geological processes in settings related to subduction, collision, and lithospheric plate sliding. Proceedings of the Third All-Russia Conference attended by foreign participants. Vladivostok: Dal'nauka, 2016. pp. 159-161. (in Russian).

20. G. S. Gousev, V. E. Khain, "On relationship between Baikal-Vitim, Aldan-Stanovoy and Mongol-Okhotsk terranes (south of central Siberia)", Geotektonika, no. 5, pp. 68-82, 1995. (in Russian).

21. L. P. Karsakov, V. A. Guryanov, M. V. Goroshko, "Stratigraphy of lower horizons of the Riphean hypostratotype (south-eastern Siberian platform)", Stratigraphy and geologic correlation, vol. 10, no. 1, pp. 47-61, 2002. (in Russian). 
22. V. E. Kirillov, N. V. Berdnikov, V. A. Guryanov, Yang Zheng-xi, "Geological Setting and Conditions of Formation of Gold-bearing Occurrences in the Southeastern Part of the Siberian Platform", Journal of Chengdu University of Technology, vol. 29, no. 2, pp. 119-130, 2002.

23. A. M. Larin, Rapakivi granites and associated rocks. St. Petersburg: Nauka, 2011. (in Russian).

24. A. M. Larin, A. B. Kotov, S. D. Velikoslavensky, Ye. B. Sal'nikova, V. P. Kovach, "Early Precambrian A-type granitoids of the Aldan shield and fold belts: sources and geodynamic settings of formation", Petrologiya, vol. 20, no. 3, pp. 1-24, 2012. (in Russian).

25. A. M. Loiselle, D. R. Wones, "Characterististics and origin of anorogenic granites", Geological Society of Amtrica Abstracts with Programs, vol. 11, no. 7, pp. 468-468,1979.

26. Yu. F. Malyshev, Yu. F. Manilov, V. A. Guryanov, "Deep structure of the eastern North Asian craton based on the geopotential field data interpretation", Litospera, no. 2. pp. 144-155, 2014. (in Russian).

27. P. G. Nedashkovsky and A. M. Lennikov, Petrology and geochemistry of the Aldan rapakivi. Moscow, Nauka, 1991. (in Russian).

28. P. G. Nedashkovsky, V. A. Guryanov, V. Ye. Kirillov, B.L. Zalishchak, "Genetic types of rare metal deposits of the Ulkan volcanogenic trough (Aldan shield, Russia)", Geologiya rudnykh mestorozhdenii, vol. 41, no. 4, pp. 329-341, 1999. (in Russian).

29. L. A. Neymark, A. M. Larin, S. Z. Yakovleva. et al., "U-Pb age of igneous rocks of the Ulkan graben (SE of the Aldan shield)", Doklady AN, vol. 323, no. 6, pp. 1152-1156,1992. (in Russian).

30. O. T. Rämö, I. Haapala, "One hundred years of Rapakivi Granite", Mineral. Petrol, vol. 52, pp. 129-185, 1995.

31. L. Songnian, Y. Chunliang, I. Huaikun, L. A. Humin, "Group of Rifting Events in the Terminal Paleoproterozoic in the North China Craton", Gondvana Research, vol. 5, no. 1, pp. 123-131, 2002.

32. G. M. Vovna, V. I. Kiselev, V. G. Sakhno, M. A. Mishkin, A. M. Lennikov, N. V. Zarubina, A. A. Veldemar, "The first data on the local U-Pb isotopic dating of zircons (LA-ICP-MS) from hypersthene plagiogneiss of the Dzhugdzhur block (SE Aldan Shield)", Doklady AN, vol. 459, no. 2, pp. 189-193, 2014. (in Russian).

33. J. - H. Yu, H.- Q. Fu, F. Zhang, M. Guan. "Geochemistry of a Rapakivi Granite Suite in the Proterozoic Rift Trough in Beijing and its Vicinity", Acta Geol Sinica, vol. 4, no. 2, pp. 169-186, 1991.

34. M. Zhai, W. Liu. "Paleoproterozoic tectonic history of the North China Craton: a review", Precambrian Research, vol. 122, pp. 183-199, 2003. 